\author{
$\stackrel{\odot}{1}$ \\ |l|

\section{GDY SŁOWO DZIELI. MOWA POGARDY I NIENAWIŚCI W RELACJACH MIĘDZY LUDŹMI}

\begin{abstract}
Monika Obrębska, Marcelina Dobrowolska, Gdy słowo dzieli. Mowa pogardy i nienawiści w relacjach między ludźmi [When the word divides. Contempt speech and hate speech in relationships between people] edited by L. Bakiera, M. Obrębska „" Człowiek i Społeczeństwo" vol. Ll: Blisko czy na dystans? Psychologiczne aspekty relacji międzyludzkich [Closely or distantly? The psychological aspects of interpersonal relations], Poznań 2021, pp. 221-239, Adam Mickiewicz University. ISSN 0239-3271, https://doi.org/10.14746/cis.2021.51.12.
\end{abstract}

Hate speech is defined as verbal abuse against minority groups. Its emotional basis is contempt which activates anger and revulsion. Therefore, it seems to be justified to speak of "contempt speech and hate speech" as a spreading social phenomenon, in effect resulting in a generalised deterioration in attitudes toward minorities. The media and public figures play a huge role in promoting hate speech, and it is also fostered by the sense of danger accompanying the COVID-19 pandemic. In order to stop this process, we should start to perceive hate speech as a serious social problem, the conditions and consequences of which should be the subject of reflection and scientific studies.

Keywords: hate speech, minority groups, social prejudices

Monika Obrębska, Uniwersytet im. Adama Mickiewicza w Poznaniu, Wydział Psychologii i Kognitywistyki, ul. Szamarzewskiego 89AB, 60-568 Poznań, e-mail: obrebska@amu.edu.pl, ORCID: https://orcid.org/0000-0003-0457-5402.

Marcelina Dobrowolska, Uniwersytet im. Adama Mickiewicza w Poznaniu, Wydział Psychologii i Kognitywistyki, ul. Szamarzewskiego 89AB, 60-568 Poznań, e-mail: mardob6@st.amu.edu.pl. 
Jedenaste: nie bądź obojętny.

Marian Turski

\section{Wprowadzenie}

Od pewnego czasu w wielu państwach demokratycznych daje się zauważyć niezwykłe nasilenie zjawiska określanego jako „mowa nienawiści” (Jakubowska i Szarota, 2020). Mass media, przestrzeń publiczna, a nawet codzienne rozmowy coraz częściej zostają zdominowane przez wypowiedzi charakteryzujące się brakiem tolerancji czy poszanowania dla drugiego człowieka. Powszechne staje się bezrefleksyjne powtarzanie stereotypów, otwarte wyrażanie niechęci i używanie obraźliwych słów. Zabójstwo prezydenta Gdańska Pawła Adamowicza, zamieszki podczas Marszu Równości w Białymstoku, uliczne protesty kobiet w reakcji na ustawę antyaborcyjną wszystkie te wydarzenia z niedawnej przeszłości są wyrazem niepokojów społecznych, radykalizacji postaw i braku dialogu. Są też przyczynkiem lub konsekwencją gwałtownego nasilenia poziomu agresji, również w sferze języka i komunikacji.

Wykorzystywanie języka w celu znieważania, pomawiania lub rozbudzania nienawiści wobec osoby lub grupy nazywane jest w literaturze „mową pogardy i nienawiści”. Pierwsze definicje ograniczały jej zakres wyłącznie do aktów przemocy werbalnej wobec grup mniejszościowych, dziś wiemy już, że może być ona skierowana do różnych grup społecznych (Bilewicz i Soral, 2020). Mnogość adresatów oraz masowość występowania mowy nienawiści sprawiły, że przestajemy postrzegać ją jako zjawisko niepożądane, a zaczynamy uważać za coś naturalnego. Większości z nas już nie dziwią obraźliwe posty czy komentarze pojawiające się w mediach społecznościowych. Lajkujemy treści, które nie tylko nie niosą żadnej wartości merytorycznej, ale też charakteryzują się otwartym brakiem tolerancji wobec wszelkiej odmienności. Akceptujemy (a nawet z ciekawością słuchamy) pojawiające się w wiadomościach nienawistne wypowiedzi celebrytów, polityków czy zwykłych obywateli. Pełni obojętności przysłuchujemy się doniesieniom o coraz częstszych aktach przemocy fizycznej, których podstawą była silna niechęć wobec drugiego człowieka. To wszystko sprawia, że mniej lub bardziej świadomie przyczyniamy się do budowania wrogiego, pełnego 
nieufności świata, w którym wszystko, co złe, przypisać możemy tym, którzy w jakiś sposób się od nas różnią. Aby powstrzymać ten proces, musimy zacząć postrzegać mowę nienawiści jako poważny problem społeczny, którego uwarunkowania i konsekwencje powinny stać się przedmiotem refleksji oraz naukowych opracowań.

Celem prezentowanego artykułu jest próba zrozumienia i integracji motywacyjnych, poznawczych i społecznych uwarunkowań mowy nienawiści, odwołujących się do klasycznych badań z zakresu psychologii społecznej nad uprzedzeniami i stereotypami, pokazanie jej psychospołecznych konsekwencji oraz wyodrębnienie cech charakterystycznych, umożliwiających precyzyjne zakwalifikowanie danej wypowiedzi do tej kategorii uzusu językowego. Artykuł jest uzupełnieniem i uaktualnieniem treści przedstawionych we wcześniejszym tekście: Contempt Speech and Hate Speech: Characteristics, Determinants and Consequences (Obrębska, 2020). Mamy nadzieję, że refleksja nad mową nienawiści uwrażliwi Czytelnika na język i jego pragmatykę, gdyż słowo jest nie tylko nośnikiem znaczeń, ale i emocji, które mogą wspierać lub osłabiać więzi pomiędzy ludźmi.

\section{Charakterystyka mowy pogardy i nienawiści}

Mowa nienawiści (hate speech) definiowana jest najczęściej jako intencjonalna i świadomie stosowana przemoc werbalna wobec grup mniejszościowych (Adamczak-Krysztofowicz i Szczepaniak-Kozak, 2017), obejmująca komunikaty poniżające, lżące, wyszydzające lub obrażające osobę bądź grupę osób ze względu na domniemaną lub rzeczywistą cechę (Jaszczyk-Grzyb, 2020). Zdaniem Mikołaja Winiewskiego i współpracowników (2017) emocjonalnym podłożem mowy nienawiści jest pogarda, która uruchamia gniew i wstręt, stąd uzasadnione wydaje się mówienie o „mowie pogardy i nienawiści” jako rozpowszechniającym się zjawisku społecznym, prowadzącym w efekcie do uogólnionego pogorszenia się postaw wobec mniejszości. Odgrywa ona ogromną rolę w obecnym życiu społecznym, jest narzędziem w walce politycznej i w debacie publicznej, wykluczając dialog i porozumienie. Prowadzić może do popełnienia tzw. zbrodni nienawiści (hate crime), polegającej na fizycznej przemocy wynikającej z antyspołecznych uprzedzeń wobec dyskryminowanej grupy społecznej. Przeprowadzona przez Jacka McDevitta, Jacka Levina i Susan Bennett (2002) analiza 169 przestępstw z nienawiści - które zostały zgłoszone oraz zbadane przez bostońską policję w okresie od lipca 1991 do grudnia 
1992 r. - wykazała, że motywowane one były głównie chęcią poczucia dreszczyka emocji (66\%) lub obrony przed tym, co obce (25\%). Wydaje się więc, że pozbawienie ofiary indywidualnej tożsamości i nadanie jej etykiety „obcego” sprawia, że jest ona postrzegana w sposób przedmiotowy, a zadawane jej cierpienie staje się sposobem na pozbycie się nudy.

Mowa nienawiści nie jest pojęciem synonimicznym z agresją językową. Zdaniem Anny Szczepaniak-Kozak i Hadriana Lankiewicza (2017) agresja językowa jest pojęciem szerszym niż mowa nienawiści i obejmuje wypowiedzi przesycone jakąkolwiek negatywną emocją, które są skierowane do drugiej osoby w reakcji na popełniony czyn lub cechę sekundarną. Mowa nienawiści jest natomiast wypowiedzią atakującą inną osobę ze względu na wybrane cechy prymarne, np. kolor skóry, rasę, narodowość, przynależność etniczną, orientację seksualną, wyznanie religijne, płeć, pochodzenie społeczne czy niepełnosprawność. Tym, co często utrudnia zakwalifikowanie danej wypowiedzi jako nienawistnej, jest to, że zawarta w niej wrogość nie zawsze jest wyrażona wprost. Czasami przybiera formę zdań pozornie wyrażających dobrą wolę, które jednak w sposób zdecydowany zaznaczają różnice między danymi kulturami lub grupami. Jak zauważają Sylwia Adamczak-Krysztofowicz i Anna Szczepaniak-Kozak (2019), takie zdania często są opatrzone komentarzem: „nie mam nic złego na myśli, mówiąc...”, „wszyscy pewnie się zgodzą, że...”, bazujących na stereotypowym ujęciu kulturowej i społecznej tożsamości danej osoby. Z pozoru stanowią one pełne szacunku uznanie różnic, np. „wszyscy Cyganie tak mają”, „Włosi zawsze się spóźniają”. W istocie prowadzą jednak do pogłębienia uprzedzeń poprzez schematyczną kategoryzację i piętnowanie jednostki, narodu czy grupy etnicznej.

Podkreślana odmienność zwykle stanowi odzwierciedlenie pewnego funkcjonującego stereotypu i prowadzi nie tylko do pogłębienia występujących uprzedzeń, ale też stygmatyzacji danej jednostki czy grupy. Pozornie neutralne zdanie: „Wszyscy wiemy, że Żydzi kontrolują światową gospodarkę”, tak naprawdę jest wyrazem istniejącej w naszej kulturze wiary w spisek żydowski, która jest najbardziej rozpowszechnioną formą antysemityzmu w Polsce (Stefaniak, Bilewicz i Winiewski, 2015). Ponadto, jak zauważa Jadwiga Linde-Usiekniewicz (2019), „nawoływanie do nienawiści” jest czynnością prelokucyjną (w sensie Austinowskim), może więc przybierać bardzo różne formy językowe. Oznacza to, że nie istnieje zamknięty katalog wyrażeń, których obecność w wypowiedzi pozwoliłaby jednoznacznie stwierdzić, że mamy do czynienia z językiem pogardy i nienawiści. Określenie, jakie konkretnie komunikaty możemy objąć ramami definicyjnymi 
opisywanego zjawiska, nie jest więc proste. Dlatego warto odwołać się do jego czterech poziomów wyróżnionych przez Iwonę Jakubowską-Branicką (2020).

Pierwszym z nich, związanym najczęściej z internetowymi wypowiedziami, jest hejt. Wyróżnia go obecność przekleństw i niecenzuralnych słów. Kolejny poziom to negatywne etykietowanie, czyli zwracanie się do kogoś w sposób wytykający mu przynależność do pewnej mniej lub bardziej dyskryminowanej grupy społecznej. Następna jest niebezpieczna mowa (dangerous speech), rozumiana jako nawoływanie do przemocy, zachęcanie do zbrodni. Natomiast ostatni, a zarazem najbardziej niebezpieczny poziom, stanowią narracje nienawiści, które promują świat dychotomiczny, spolaryzowany. Nie ma w nim miejsca na tolerancję, gdyż jest on jasno podzielony na dobrych „nas” i wrogich „was”. Stąd używanie mowy nienawiści wobec przedstawicieli grupy obcej jest w nim całkowicie usprawiedliwione i moralnie zasadne.

Podsumowując, znamienne dla mowy nienawiści jest to, że przyczynia się ona do podtrzymywania uprzedzeń społecznych oraz postrzegania innych przez pryzmat grupy, z którą ich utożsamiamy, a więc w sposób uproszczony i schematyczny. W narracjach nienawiści świat jest konsekwentnie bezprzedmiotowy, nie występują w nim poszczególne jednostki, ale jedynie reprezentanci stron, rzeczywistość podlega zaś tendencyjnej interpretacji. Psychologiczne wyznaczniki stosowania mowy nienawiści mogą być związane zarówno ze zmiennymi osobowościowymi, jak i odnoszącymi się do poglądów osoby na temat porządku społecznego. Duże znaczenie odgrywa również kontekst społeczny, szczególnie sytuacja zagrożenia wyzwalająca negatywne emocje (przede wszystkim lęk), wzmagająca stereotypizację i tendencję do faworyzowania swoich (Kossowska, Szumowska i Szwed, 2018), co obrazuje obecna sytuacja pandemii COVID-19, opisana w ostatnim paragrafie.

\section{Uwarunkowania mowy pogardy i nienawiści}

Analiza zmiennych demograficznych przeprowadzona przez Centrum Badań nad Uprzedzeniami Uniwersytetu Warszawskiego (Winiewski i in., 2017) pozwoliła wskazać grupy osób najczęściej posługujące się mową nienawiści. Jest ona stosowana częściej przez mężczyzn niż przez kobiety, jest bardziej powszechna wśród osób młodszych niż starszych i powiązana z niższym poziomem wykształcenia. Częściej używanie obraźliwej wobec mniejszości 
retoryki zgłaszały osoby o sympatiach prawicowych; taka zależność szczególnie widoczna była w przypadku młodzieży. Nie zaobserwowano natomiast znaczących różnic pomiędzy osobami mieszkającymi w mniejszych i większych miejscowościach, nieistotny okazał się też poziom religijności.

Aby zidentyfikować mechanizm odpowiedzialny za różnice wśród tych grup, należy jednak przyjrzeć się rozmaitym czynnikom socjopsychologicznym. Psychologiczne wyznaczniki stosowania mowy nienawiści mogą być związane zarówno z indywidualnymi zmiennymi osobowościowymi, jak i ze zmiennymi odnoszącymi się do poglądów osoby na temat porządku społecznego. Znaczenie mieć może także sytuacja społeczna, szczególnie generująca poczucie zagrożenia i niepewności (Kossowska i in., 2018).

W badaniach przeprowadzonych przez Winiewskiego i jego zespół (2017) zaobserwowano, że mowa nienawiści jest stosowana częściej przez osoby o niższej samoocenie. Romin W. Tafarodi i William B. Swann (1995), mierząc samoocenę za pomocą powszechnie stosowanej skali Rosenberga, wykazali, że na globalne poczucie własnej wartości składają się dwa względnie odrębne, choć silnie powiązane ze sobą czynniki: przekonanie o własnej kompetencji i akceptacja siebie. Samoocena, będąc silnie nasycona przekonaniami o podmiotowej kontroli, powinna więc obniżać się wraz ze wzrostem uprzedzeń i nienawistnych komunikatów. Jak wykazano w przeprowadzonym we Włoszech badaniu (Garofalo, Holden, Zeigler-Hill i Velotti, 2016), łącznikiem między niską samooceną a agresją mogą być problemy z regulacją emocji. Jej niski poziom prowadzi do utraty kontroli nad przeżywanymi stanami emocjonalnymi oraz trudności w rozumieniu i identyfikowaniu własnych emocji podstawowych - złości, smutku, strachu, wstrętu i radości (Mennin, Heimberg, Turk i Fresco, 2005). Zamiast tego doświadcza się emocji jako niezróżnicowanych i zbyt obciążających. Biorąc pod uwagę siłę reakcji emocjonalnych, niezdolność do wykorzystania emocji w sposób funkcjonalny i negatywną reakcję na własne emocje, Mennin z zespołem (2005) zakładają, że niski poziom regulacji emocji sprzyja angażowaniu się w wiele sposobów regulowania emocji, które okazują się nieadaptacyjne. Posługiwanie się mową nienawiści, ogniskującą agresję na inne osoby, można uznać za nieadaptacyjny sposób radzenia sobie z negatywnymi i nieuświadamianymi emocjami (Wypych i in., 2020). Biorąc pod uwagę fakt, że największą skłonność do nienawistnych wypowiedzi mają ludzie młodzi, zasadne wydaje się twierdzenie, że to właśnie brak umiejętności radzenia sobie z emocjami może być przyczyną ich większej wrogości werbalnej.

Globalna samoocena jako forma reprezentacji Ja często badana jest również w kontekście postaw autorytarnych (Radkiewicz, 2012). Pośrednich 
przesłanek na temat związku tych zmiennych szukać można w badaniach pokazujących, że autorytarny styl wychowania stosowany wobec dzieci wpływa na obniżenie ich samooceny w dorosłym życiu (Martinez i Garcia, 2008). Na opisaną przez Thomasa W. Adorna (1950) osobowość autorytarną składają się takie cechy, jak konwencjonalizm, autorytarna agresja, przesądność i stereotypowość, wrogość i projekcja niebezpieczeństwa. Obecnie autorytaryzm badacze wiążą raczej ze sposobem widzenia świata, i to świata społeczno-politycznego, aniżeli ze strukturą osobowości (Kossowska, 2005; Radkiewicz, 2012). Zwraca się uwagę, że w sytuacji zagrożenia, alienacji i poczucia bezsilności wzrasta akceptacja dla idei, które dają poczucie siły i bezpieczeństwa oraz redukują lęk. Marek Błażewicz (2017) badał związki wzbudzanej niepewności Ja, autorytaryzmu, identyfikacji grupowej oraz postaw wobec imigrantów. Wywołana eksperymentalnie niepewność Ja powodowała wystąpienie reakcji autorytarnej i uaktywnienie negatywnych postaw. Jednocześnie identyfikacja grupowa zapobiegała negatywnym reakcjom wobec obcych.

Pewną kontynuacją idei autorytaryzmu jest koncepcja prawicowego autorytaryzmu. Według Boba Altemeyera (1996) jednostka uzyskująca wysokie wyniki na skali prawicowego autorytaryzmu charakteryzuje się postawą autorytarnej uległości, postawą autorytarnej agresji oraz postawą konwencjonalizmu. Autorytarna agresja dopuszcza możliwość użycia siły i przemocy wobec osób, które nie stosują się do zasad wyznaczonych przez autorytet. Konwencjonalizm to postawa dbania o przestrzeganie ustalonych norm. Zawiera w sobie restrykcyjne zasady wobec seksualności, ról płciowych i tradycji narodowej. W badaniach prawicowy autorytaryzm wielokrotnie korelował z uprzedzeniami (Ekehammar, Akrami, Gylje i Zakrisson, 2004; McFarland, 2010; Crawford, Brandt, Inbar i Mallinas, 2016). Autorzy wiążą te fakty z poczuciem zagrożenia występującego u osób autorytarnych, związanego z obawą o utratę pozycji oraz zmniejszenia znaczenia tradycyjnych wartości i dotychczasowego porządku społecznego.

Prace nad autorytaryzmem skłoniły Miltona Rokeacha (1960) do opracowania narzędzia do jego pomiaru, które umożliwiałoby uchwycenie różnych aspektów autorytaryzmu nieideologicznego, czyli manifestującego się niezależnie od treści przekonań politycznych. Prace te zaowocowały nie tylko wprowadzeniem nowej skali do pomiaru nieideologicznego autorytaryzmu, ale i pojęciem dogmatyzmu, które miało opisywać umysł osoby nieideologicznie autorytarnej. Głównym rysem takiej umysłowości jest zamkniętość systemu przekonań i jego odporność na zmianę, czego konsekwencją jest m.in. skłonność do uproszczonego i stereotypowego spostrzegania 
rzeczywistości. Dogmatyzm wiąże się również z orientacją na dominację społeczną, definiowaną jako zorientowanie na rywalizację z innymi grupami społecznymi, dominowanie nad nimi oraz niechętny stosunek wobec równości społecznej (Pratto, Sidanius, Stallworth i Malle, 1994; Ekehammar i in., 2004; McFarland, 2010). Pokrewnym konstruktem jest także potrzeba poznawczego domknięcia, polegająca na dążeniu do posiadania wiedzy pewnej i awersji wobec wieloznaczności (Kruglanski i Webster, 1996). Sprzyja większemu faworyzowaniu grupy własnej i umniejszaniu znaczenia grupy obcej (Shah, Kruglanski i Thompson, 1998). W jednym z badań mierzono potrzebę domknięcia poznawczego obok prawicowego autorytaryzmu, orientacji na dominację społeczną, rasizmu i konserwatywnych przekonań. Okazało się, że potrzeba domknięcia poznawczego ma wpływ na rasizm i konserwatywne przekonania, a mediatorem tego związku jest prawicowy autorytaryzm oraz częściowo orientacja na dominację społeczną (Van Hiel, Pandelaere i Duriez, 2004).

W ostatnich latach można też zaobserwować rosnące zainteresowanie relacją między podmiotową kontrolą a stosunkami międzygrupowymi (Kofta, Narkiewicz-Jodko i Kobyliński, 2011). Przedmiotem ożywionych dyskusji jest zwłaszcza rola poczucia kontroli w procesach identyfikacji z grupą własną, w relacjach współzależności z innymi grupami oraz w procesach stereotypizacji i powstawania uprzedzeń międzygrupowych (por. Fritsche, Jonas i Fankhaenel, 2008; Rutjens i Loseman, 2010; Sullivan, Landau i Rothschild, 2010). Tym ostatnim procesom sprzyja zwłaszcza deprywacja kontroli i jej zewnętrzny charakter (Kofta i in., 2011). Procesy myślowe i zachowania osób zewnątrzsterownych w ogromnym stopniu podlegają regulacji przez czynniki zewnętrzne. Są one zazwyczaj uległe, konformistyczne, posłuszne wobec władzy i akceptujące społeczne nierówności. Częściej także ujawniają agresję i negatywne postawy społeczne.

Psychologiczne wyznaczniki stosowania mowy nienawiści mogą być więc związane zarówno z kontrolą emocji i poziomem samooceny, z formalną strukturą przekonań i sposobem przetwarzania informacji, jak i ze zmiennymi odnoszącymi się do poglądów osoby na temat porządku społecznego. Negatywne emocje mogą też pełnić funkcję swoistego bodźca prymującego określony sposób myślenia o grupach obcych (Niedenthal, Krauth-Gruber i Ric, 2006). Zdaniem Alberta Bandury (2007) agresja ma największą szansę bezpośredniej ekspresji, kiedy pojawia się paralelizm dwóch zjawisk: przeżywanie negatywnych emocji (złość, poczucie krzywdy, lęk), generujące skłonność do wrogich i agresywnych zachowań, oraz pewien system przekonań o świecie społecznym, który osłabia moralne i społeczne 
hamulce powstrzymujące wyrażanie tej skłonności. Ów system to wiara w „zagrażający świat”, ideologiczny lęk społeczny, czyli permanentne przekonanie, że porządek świata otaczającego jednostkę jest przez kogoś zagrożony. O przyczynach tych zagrożeń i ich strukturze informują nas najczęściej środki masowego przekazu, których rola w promowaniu mowy nienawiści jest często niedoceniana.

\section{Rola mediów w upowszechnianiu mowy pogardy i nienawiści}

Okazuje się (Winiewski i in., 2017), że dorośli Polacy najczęściej stykają się z mową nienawiści w telewizji i w rozmowach ze znajomymi, nieco rzadziej w Internecie czy miejscach publicznych. Z kolei młodzież deklaruje, że to głównie Internet jest miejscem, w którym najczęściej spotykają się z nienawistną formą komunikacji. Następne w kolejności są rozmowy ze znajomymi, miejsca publiczne oraz telewizja. Obie grupy wskazały także radio i prasę, co oznacza, że wszystkie środki społecznego komunikowania są nią w jakimś stopniu zainfekowane - również media społecznościowe.

Obecnie z mediów społecznościowych aktywnie korzysta 3,8 mld użytkowników, w tym 19 mln Polaków (Hootsuite, 2020). Są to osoby o różnych poglądach, pochodzeniu, orientacji seksualnej czy statusie socjoekonomicznym. Razem tworzą niezwykle zróżnicowaną grupę, która codziennie - za pośrednictwem zdjęć, lajków i postów - dzieli się z innymi swoimi radościami, smutkami i przemyśleniami. Mogłoby się zatem wydawać, że im więcej osób zrzeszy dany portal, tym łatwiejsze dla jego użytkowników będzie poznawanie świata z wielu różnych perspektyw. Tymczasem tak się nie dzieje. Dlaczego? Odpowiedzi na to pytanie udzielił w swoim wystąpieniu na konferencji TED w 2011 r. Eli Pariser. Zauważył on, że Internet oraz portale społecznościowe już dawno przestały nas łączyć, a zaczęły zamykać w bańkach informacyjnych (filter bubbles). Innymi słowy, padliśmy ofiarą algorytmicznej i niewidzialnej selekcji treści. Żyjemy otoczeni przez informacje, które zostały dla nas wybrane na podstawie tego, kim jesteśmy, skąd pochodzimy i z jakiego sprzętu korzystamy. Widzimy tylko to, co według algorytmu chcemy zobaczyć, nie zaś to, co zobaczyć powinniśmy. W skali mikro oznacza to, że treści w jakiś sposób dla nas niewygodne, kontrowersyjne, po prostu przestają do nas docierać. Natomiast w skali makro filtracja ta doprowadzić może do osłabienia dyskursu publicznego, stanowiącego podstawę zdrowej demokracji (Malinowski, 2016). 
A zatem platformy, które miały nas do siebie zbliżać, raczej nas dzielą oraz upośledzają naszą zdolność do kulturalnej rozmowy i dyskusji. Po tygodniach, miesiącach czy nawet latach spędzonych na informacyjnej diecie, ułożonej specjalnie dla nas przez portale społecznościowe, łatwo jest zacząć postrzegać ludzi o odmiennych poglądach czy opiniach jako niedoinformowanych i nieczytających wiadomości. Problem polega jednak na tym, że oni je czytają - tylko w innej wersji niż my. Mówiąc wprost, media społecznościowe zmniejszyły naszą zdolność do sympatyzowania z ludźmi, którzy się z nami nie zgadzają, oraz dały nam przyzwolenie na traktowanie ich z pogardą - ostatecznie, gdyby byli rozsądni, to przecież by się z nami zgadzali (Ormerod, 2018; Müller i Carlo, 2020).

Dużą rolę w propagowaniu mowy nienawiści odgrywają również wypowiadające się w mediach osoby publiczne, szczególnie politycy. Chociaż w społeczeństwie demokratycznym spór między politycznymi rywalami uważany jest za sposób dochodzenia do optymalnych rozwiązań, to w praktyce często przekształca się on w akty agresji między spierającymi się stronami - i nie prowadzi ani do dobrych rozwiązań, ani do kompromisu (Skarżyńska, 2020). Według Michała Bilewicza (2017) aktorzy polskiej sceny politycznej zaczęli powszechnie wykorzystywać język pogardy i nienawiści po roku 2015, w którym rozpoczął się kryzys migracyjny w Europie. W swoich wypowiedziach otwarcie atakowali uchodźców, co do tej pory się nie zdarzało - przynajmniej nie na taką skalę. Po tragicznej śmierci prezydenta Gdańska Pawła Adamowicza w 2019 r. nastąpiło chwilowe opamiętanie. Wielu polityków wyrażało w mediach swój zdecydowany sprzeciw przeciwko wykorzystywaniu mowy nienawiści w debacie publicznej, a już zwłaszcza w debacie politycznej. Niestety bardzo szybko okazało się, że walka z mową nienawiści jest uzasadniona tylko wtedy, gdy posługują się nią opozycjoniści. Dziś, dwa lata po tym wydarzeniu, śmiało możemy powiedzieć, że poziom werbalnej agresji wśród naszych polityków zdecydowanie wzrósł. Radykalizacja konserwatywnej prawicy wywołuje wrogość i pogardę po drugiej stronie sceny politycznej. W ten sposób powstaje błędne koło nienawiści, z którego coraz trudniej się wyzwolić (Jakubowska i Szarota, 2020).

Według Bilewicza (2017) współcześni wyborcy to ludzie niemal permanentnie podłączeni do sieci, która jest pełna wrogich, pełnych pogardy wypowiedzi. Dlatego politycy, by zaistnieć, a później utrzymać się na scenie politycznej, są niejako zmuszeni do używania mowy nienawiści. Jest ona bowiem nie tylko znanym, ale też rozumianym i coraz szerzej akceptowanym przez suwerena sposobem porozumiewania się. Ponadto wykorzystywanie 
przez polityków mowy nienawiści nierzadko bazuje na znanej od wieków metodzie motywowania do działania i przekonywania do swoich racji, jaką jest wzbudzanie strachu. Czasami w swoich wypowiedziach odwołują się do uzasadnionych obaw obywateli, np. mówią, że przez antyszczepionkowców możemy nie pokonać pandemii COVID-19. Często jednak opierają się na lękach irracjonalnych, wynikających z wszelkiego rodzaju uprzedzeń, np. utrzymują, że społeczności LGBT są zagrożeniem dla polskich rodzin. Komunikaty te wywierają na nas silny wpływ, ponieważ odczuwając strach, przestajemy myśleć racjonalnie. Naszym jedynym celem staje się usunięcie zagrożenia (Pratkanis i Aronson, 2004).

Mowa nienawiści może być też elementem negatywnej kampanii politycznej, która opiera się na spersonalizowanych atakach na politycznego przeciwnika. Ma ona przede wszystkim zniechęcić wyborców do głosowania na cel ataku, umożliwić porównanie obu kandydatów (ja - dobry, on - zły) oraz doprowadzić do polaryzacji postaw wyborczych w elektoracie (Cwalina i Falkowski, 2005). Język pogardy i nienawiści będzie szczególnie widoczny w negatywnej reklamie wizerunkowej oraz reklamie atakującej, które wcale nie muszą przybierać formy spotu puszczanego w telewizji. Ta pierwsza całkowicie pomija kwestie programu wyborczego kandydata, skupiając się m.in. na jego cechach charakteru, życiu osobistym oraz seksualnym, a także powiązaniach z różnymi grupami społecznymi, np. w czasie kampanii prezydenckiej w 2020 r. europosłanka Beata Kempa (zwolenniczka Andrzeja Dudy) zaatakowała Roberta Biedronia, wytykając mu jego orientację seksualną słowami: „Panie Biedroń, widzimy, jak pan i kandydatka na pierwszą damę, radośnie oklaskujecie ataki na Polskę”. Ta druga natomiast będzie opierała się na rozpowszechnianiu plotek, insynuacji, stosowaniu niedomówień i kłamstw oraz obrzucaniu przeciwnika epitetami. Przykładem takiej reklamy były pojawiające się w całej Polsce podczas kampanii samorządowej w 2018 r. banery z wizerunkiem Jarosława Kaczyńskiego głoszące m.in.: „PiS wziął miliony i chce być bezkarny” oraz „PiS wziął miliony, a ludzi nie stać na leki”. Wykorzystywanie tego typu przekazów w kampanii może doprowadzić do jednej z trzech konsekwencji: wzrostu poparcia, jego utrzymania lub obniżenia - i to dla każdego z kandydatów, czyli zarówno dla atakującego, jak i atakowanego. Co ciekawe, wpływ negatywnej kampanii na preferencje wyborcze rzadko jest zgodny z zamierzeniami nadawcy. Mimo to współczesne kampanie wyborcze wyraźnie pokazują, że jej popularność nie spada, ale wręcz odwrotnie - wzrasta, rozpowszechniając agresywną formę komunikacji bazującą na mowie pogardy i nienawiści. 


\section{Konsekwencje mowy pogardy i nienawiści}

Mowa nienawiści niesie ze sobą wiele negatywnych konsekwencji na różnych poziomach. Na poziomie jednostkowym może prowadzić do znacznego pogorszenia funkcjonowania psychospołecznego członków mniejszości. Laura Leets i Howard Giles (1999) wskazują że reakcje na harmful speech podobne są do tych, które pojawiają po wystąpieniu traumatycznych przeżyć. Na skutek utraty godności pojawiają się silne reakcje emocjonalne: przygnębienie, gniew i smutek. Po jakimś czasie przedstawiciele mniejszości próbują zrozumieć, co ich spotkało, przypisując winę całej grupie większościowej. Z czasem u ofiar pojawia się nienawiść i żal, a w niektórych przypadkach agresja fizyczna i psychiczna, która może przejawiać się np. w zachowaniach chuligańskich. W większości przypadków jednak negatywne emocje są tłumione i mogą prowadzić do powstawania depresji, wyuczonej bezradności oraz różnorodnych form ucieczki od problemów w postaci narkomanii czy alkoholizmu. Mowa nienawiści może również doprowadzać do powstawania aktów autoagresji, w tym samookaleczeń i prób samobójczych (Mullen i Smyth, 2004), utrudniając znacząco integrację danej grupy z większością społeczeństwa (Mullen i Rice, 2003).

Wyniki ankiety przeprowadzonej wśród Norwegów z różnego typu niepełnosprawnościami (Vedeler, Olsen i Eriksen, 2019) wskazują, że aż 38\% z nich przynajmniej raz w ciągu ostatnich dwunastu miesięcy doświadczyło mowy nienawiści. Ustalono, że doznają oni związanych z nią niepożądanych konsekwencji przede wszystkim w trzech obszarach: psychologicznym (zmniejszona pewność siebie, depresja i obniżona jakość życia), towarzyskim (unikanie pewnych sytuacji i miejsc) oraz społecznym (unikanie publicznego wyrażania opinii). Okazało się ponadto, że im bardziej osoby z niepełnosprawnościami były zintegrowane ze społeczeństwem, tym rzadziej były narażone na kontakt z językiem pogardy i nienawiści. I tutaj, niestety, mamy do czynienia z błędnym kołem, gdyż osoby, które zetknęły się z mową nienawiści, mają tendencję do wycofywania się z kontaktów społecznych, a więc chcąc chronić siebie, jednocześnie pozbawiają się w pewnym sensie szansy na skorzystanie ze skutecznego środka ochrony, którym - jak wynika z odpowiedzi innych respondentów - jest wzmocnienie więzi z innymi ludźmi.

Również w naszym kraju sprawdzano, jaki wpływ na funkcjonowanie jednostki ma doświadczanie mowy nienawiści. Badanie przeprowadzone 
wśród studentów zagranicznych na Uniwersytecie Warszawskim wykazało, że ci, wobec których został użyty język pogardy i nienawiści, charakteryzowali się zdecydowanie gorszym nastrojem, niższym dobrostanem psychicznym, a także wyższym poziomem stresu pourazowego. Natomiast gdy grupę badawczą stanowiły mniejszości LGBT, stwierdzono, że im częściej jej przedstawiciele spotykali się z antygejowską lub antylesbijską mową nienawiści, tym poważniejszych objawów depresji doświadczali oraz częściej myśleli o samobójstwie (Bilewicz i Soral, 2020).

Mowa nienawiści nie tylko zostawia uraz w psychice osób dyskryminowanych, ale też zmienia sposób, w jaki postrzegane są grupy mniejszościowe przez resztę społeczeństwa. Osoby dotychczas tolerancyjne po kontakcie z językową agresją zmienić mogą postawę w stosunku do grup dyskryminowanych, wychodząc z założenia, że jeżeli tak ocenia je większość, to muszą być one w jakimś stopniu odpowiedzialne za nieprzychylności, które je spotykają. Fabio Fasoli ze współpracownikami (2015) wykazali, że zarówno świadome, jak i nieświadome zetknięcie się z homofobicznymi epitetami sprzyjało dehumanizacji osób homoseksualnych: badani przypisywali im mniej słów związanych z ludźmi w ogóle, takich jak obywatel, kultura czy twarz. Zależność ta nie wystąpiła w warunkach kontrolnych, czyli wtedy, gdy zamiast homofobicznego epitetu pojawiała się neutralna etykieta (np. gej/homoseksualista) lub ogólna zniewaga (np. dupek). Co więcej, eksperymentatorom udało się także znaleźć dowody na to, że podświadoma percepcja homofobicznych epitetów wpływa na rzeczywiste zachowania osób heteroseksualnych. Okazało się bowiem, że pod wpływem nieświadomie odebranych obraźliwych bodźców miały one tendencję do fizycznego dystansowania się od osoby homoseksualnej, z którą miały wejść w interakcję.

Badania Fasolego i zespołu (2015) pokazują, że już sama ekspozycja na mowę nienawiści zwiększa skłonność do dehumanizacji, sprawia też, że po pewnym czasie przestaje się ją uważać za obraźliwą, szokującą i naruszającą standardy społeczne. Takie wnioski można wysnuć również z badań nad desensytyzacją na obrazy przemocy (Carnagey i Anderson, 2003; Bartholow, Bushman i Sestir, 2006; Allen, Anderson i Bushman, 2018). Wykazano w nich, że częste oglądanie scen przemocy skutkuje uznaniem ich po pewnym czasie za mniej szkodliwe, a nawet zwiększa skłonność do stosowania przemocy. Do podobnych wniosków w swoim badaniu doszli Wiktor Soral, Michał Bilewicz i Mikołaj Winiewski (2018): częste i powtarzające się narażenie na mowę nienawiści prowadzi do znieczulenia na tę formę przemocy werbalnej, a następnie do niższej oceny ofiar 
i większego dystansowania się, co w konsekwencji zwiększa uprzedzenia grupowe.

Kontakt z mową nienawiści kształtuje nie tylko indywidualne postawy, ale także poglądy na temat tego, w jaki sposób państwo powinno rozwiązywać problemy społeczne; w tym sensie mowa nienawiści może się stać czynnikiem kształtującym rzeczywistość polityczną społeczeństwa. Przeprowadzone przez Winiewskiego i współpracowników (2017) badanie pokazało, że kontakt z antyimigrancką mową nienawiści - poprzez budowanie strachu i nieprzychylności - może zmniejszać chęć udzielenia pomocy imigrantom i uchodźcom oraz skłaniać do większego poparcia dla państwa stosującego przemoc i inwigilację. Konsekwencją częstego kontaktu z mową nienawiści jest więc wyższy poziom uprzedzeń i tendencja do dyskryminacji grup mniejszościowych, mniejsza skłonność do przestrzegania norm społecznych, większe poparcie dla stosowania przez państwo przemocy oraz radykalizacja polityczna. Zależności te są szczególnie widoczne wśród młodzieży, jednocześnie najbardziej narażonej na kontakt z mową nienawiści (Bera, 2019). Oczywiście trudno jednoznacznie rozstrzygnąć, czy to mowa nienawiści prowadzi do zmian społecznych, czy też jest ich konsekwencją. Ale z pewnością jest ich ważnym elementem, stanowiąc sposób komunikacji uprzedzeń wobec mniejszości i przez to wywołując wiele zmian u swoich odbiorców. I jak zauważa Bilewicz (2015: 27), „traci na tym całe społeczeństwo, a Polska - jako kraj pozwalający na takie słowa - w oczywisty sposób zaczyna być traktowana jako miejsce nieprzyjazne osobom odmiennego koloru skóry, innej narodowości czy orientacji seksualnej”.

\section{Zakończenie}

Piszemy ten artykuł podczas ogólnoświatowej pandemii wirusa COVID-19. Cały czas rośnie liczba zarażonych oraz ofiar wirusa na świecie. Ludzkość pogrążona jest w chaosie, poczuciu zagrożenia i niepewności. Zamknięte zostały granice krajów, a „obcy” stał się znowu kategorią budzącą lęk i agresję. „Lęk przed wirusem przywołał automatycznie najprostsze atawistyczne przekonanie, że winni są jacyś obcy i to oni zawsze skądś przynoszą zagrożenie”, pisze Olga Tokarczuk (2020) w felietonie Okno.

Jak zauważa Bilewicz (2020), fakt, że realne bądź wyobrażone zagrożenie patogenami prowadzi do wzrostu uprzedzeń, jest całkowicie wytłumaczalny. Chroniąc się przed zagrożeniem, ludzie odcinają się od wszystkich obcych, zamykają we własnych wspólnotach, a czasem zaczynają dyskryminować 
wszystkich tych, którzy kojarzą im się z chorobą. Potwierdzają to zarówno badania naukowe, jak i przykłady historyczne. W połowie XV w. francuskie miasto Arras nawiedziła zaraza, która uśmierciła co piątego mieszkańca. Wkrótce w mieście rozpoczęły się polowania na czarownice, mordy Żydów, a miasto pogrążyło się w „inkwizycyjnym szaleństwie” (Bilewicz, 2020). Mark Schaller, Douglas Kenrick, Rebecca Neel i Steven Neuberg (2017) po latach badań stwierdzili, że obecność patogenów w otoczeniu zwiększa etnocentryzm (przywiązanie do swoich i niechęć do obcych), wzmaga konserwatyzm, zmniejsza otwartość na nowe doświadczenia, wzmacnia relacje rodzinne i wiarę religijną. Samo przywołanie myśli o zarazkach podwyższa u badanych niechęć do imigrantów odległych kulturowo - w czasie epidemii wirusa Ebola w Stanach Zjednoczonych zauważono wyraźny wzrost homofobii. Badania Julie Y. Huang, Alexandry Sedlovskiej, Joshui M. Ackermana i Johna A. Bargha (2011) pokazały, że u osób szczepionych na grypę i zabezpieczających się przed chorobą częstym myciem rąk świadomość epidemii nie prowadzi do wzrostu uprzedzeń i ksenofobii. Wydaje się zatem, że uprzedzenia stanowią faktycznie rodzaj automatycznej psychologicznej obrony przed ryzykiem zakażenia. Obrony, jak zauważa Bilewicz (2020), nieświadomej i nadmiarowej. Gdy ryzyko maleje, skłonność do uprzedzeń również.

Możemy więc spodziewać się jako jednej z psychospołecznych konsekwencji pandemii wzrostu uprzedzeń i nasilenia mowy nienawiści. Już teraz Internet kipi wręcz od hejtu, w mediach trwają polityczne przepychanki, Donald Trump nazwał COVID-19 „chińskim wirusem”, a Europa zamyka swoje granice przed jego „brytyjską” mutacją. Poczucie zagrożenia generuje potrzebę znalezienia winnych, prowadzi do radykalizacji postaw, buduje społeczną hierarchię, obniża poziom zaufania społecznego (Kossowska i in., 2018; Nycz i Obrębska, 2020). Zarazki zmieniają też sposób myślenia o moralności (Brock i in., 2019). W krajach, gdzie zagrożenie patogenami jest mniejsze, ludzie za niemoralne uważają głównie krzywdzenie innych czy niesprawiedliwy podział dóbr. W krajach o silnym rozpowszechnieniu patogenów za najbardziej niemoralne uważa się znieważenie symboli religijnych czy narodowych, obrazę autorytetów i nienormatywne zachowania seksualne. Konsekwencją pandemii może być zatem silna polaryzacja postaw, która wzmaga napięcia i konflikty międzygrupowe, podgrzewa nastroje społeczne, trwale niszczy potrzebę współdziałania i poczucie solidarności (Kossowska, Letki, Zaleśkiewicz i Wichary, 2020). Grozi nam więc autorytaryzm, radykalizacja poglądów, nasilenie uprzedzeń wobec „obcych”. Wszystkie te bolączki współczesnego świata będą się nasilać, gdy lęk przed 
wirusem powiązany zostanie z ogólnym poczuciem bezradności wobec skali zagrożenia.

Zapobiec jej może - zdaniem Małgorzaty Kossowskiej i współpracowników (2020) - podkreślanie podobieństw i budowanie wspólnoty poprzez włączanie w kategorię „my” (Polacy) innych cierpiących, pokazywanie, że jednoczy nas walka z wirusem, że sobie wzajemnie pomagamy. Ważne jest poczucie, że kryzys dotyka nas wszystkich w takim samym stopniu, gdyż ludzie stają się wówczas gotowi do poświęcenia swoich osobistych celów na rzecz wsparcia wspólnoty. Znaczącą rolę odgrywa przy tym wzbudzanie emocji moralnych (np. współczucia), facylitujących zachowania prospołeczne, oraz zaufania do różnych grup społecznych (polityków, lekarzy, naukowców), gdyż umożliwia ono skoordynowaną współpracę na wielu poziomach. W promowaniu prospołecznych i wspólnotowych wartości ogromną rolę odgrywają media i cieszące się zaufaniem społecznym osoby publiczne. Kończymy ten artykuł wyrażeniem nadziei, że trudna sytuacja w czasie pandemii okaże się mimo wszystko doświadczeniem integrującym i budującym społeczną wrażliwość, również na słowa, które nie muszą dzielić, lecz mogą łączyć i umacniać.

\section{Literatura}

Adamczak-Krysztofowicz, S., Szczepaniak-Kozak, A. (2017). A disturbing view of intercultural communication: Findings of a study into hate speech in Polish. Linguistica Silesiana, 38, 285-310.

Adamczak-Krysztofowicz, S., Szczepaniak-Kozak, A. (2019). Przeciw mowie nienawiści. Uczyć Lepiej, 4, 8-9.

Adorno, T.W. (1950/2010). Osobowość autorytarna. Warszawa: Wydawnictwo Naukowe PWN.

Allen, J.J., Anderson, C.A., Bushman, B.J. (2018). The general aggression model. Current Opinion in Psychology, 19, 75-80.

Altemeyer, B. (1996). The Authoritarian Specter. Cambridge, MA: Harvard University Press. Bandura, A. (2007). Teoria społecznego uczenia się. Warszawa: Wydawnictwo Naukowe PWN.

Bartholow, B.D., Bushman, B.J., Sestir, M.A. (2006). Chronic violent video game exposure and desensitization to violence: Behavioral and event-related brain potential data. Journal of Experimental Social Psychology, 42(4), 532-539.

Bera, R. (2019). Mowa nienawiści źródłem przemocy i agresji. Annales UMCS, 32(3), 59-66.

Bilewicz, M. (2015). Polak mówi o Obcym - psychologia mowy nienawiści. Remapping Europe, 24-27. https://www.academia.edu/10815382/Polak_mówi_o_Obcym_-_psychologia_mowy_nienawiści (dostęp: 13.02.2021).

Bilewicz, M. (2017). PO? PiS? Nieważne. Tyle nienawiści nie było w Polsce od dawna. KrytykaPolityczna.pl (dostęp: 13.02.2021). 
Bilewicz, M. (2020). Koronawirus uprzedzeń i ksenofobii. Jak patogeny wpływają na poglądy? Gazeta Wyborcza, 7.03.2020.

Bilewicz, M., Soral, W. (2020). Hate speech epidemic: The dynamic effects of derogatory language on intergroup relations and political radicalization. Advances in Political Psychology, 41, 3-33.

Błażewicz, M.A. (2017). Autorytaryzm, niepewność Ja, identyfikacja grupowa i postawy wobec grupy obcej (niepublikowana rozprawa doktorska). https://depotuw.ceon.pl/ handle/item/2532?show=full (dostęp: 10.01.2021).

Brock, B., Vauclair, C., Loughnan, S., Bain, P., Ashokkumar, A., Becker, M., Bilewicz, M., Collier-Baker, E., Crespo, C., Eastwick, P., Fischer, R., Friese, M., Gomez, A., Guerra, V., Guevara Castellanos, J., Hanke, K., Hooper, N., Huang, L., Junqi, S., Karasawa, M. (2019). Explaining illness with evil: Pathogen prevalence fosters moral vitalism. Proceedings of the Royal Society B: Biological Sciences, 286(1914).

Carnagey, N.L., Anderson, C.A. (2003). Theory in the study of media violence: The general aggression model. W: D.A. Gentile (red.), Media Violence and Children (ss. 87-106). Westport: Praeger.

Crawford, J., Brandt, M., Inbar, Y., Mallinas, S.R. (2016). Right-wing authoritarianism predicts prejudice equally toward „gay men and lesbians” and „homosexuals”. Journal of Personality and Social Psychology, 111(2), 31-45.

Cwalina, W., Falkowski, A. (2005). Marketing polityczny: perspektywa psychologiczna. Gdańsk: Gdańskie Wydawnictwo Psychologiczne.

Ekehammar, B., Akrami, N., Gylje, M., Zakrisson, I. (2004). What matters most to prejudice: Big five personality, social dominance orientation, or right-wing authoritarianism? European Journal of Personality, 18(6), 463-482.

Fasoli, F., Paladino, M.P., Carnaghi, A., Jetten, J., Bastian, B., Bain, P.G. (2015). Not ,just words”: Exposure to homophobic epithets leads to dehumanizing and physical distancing from gay men. European Journal of Social Psychology, 46(2), 237-248.

Fritsche, I., Jonas, E., Fankhaenel, T. (2008). The role of control motivation in mortality salience effects on ingroup support and defense. Journal of Personality and Social Psychology, 95, 524-541.

Garofalo, C., Holden, C.J., Zeigler-Hill, V., Velotti, P. (2016). Understanding the connection between self-esteem and aggression: The mediating role of emotion dysregulation. Aggressive Behavior, 42(1), 3-15.

Hootsuite. (2020). Digital 2020. Vancouver.

Huang, J., Sedlovskaya, A., Ackerman, J., Bargh, J. (2011). Immunizing against prejudice: Effects of disease protection on attitudes toward out-groups. Psychological Science, 22(12), 1550-1556.

Jakubowska, U., Szarota, P. (2020). Nienawiść w przestrzeni publicznej. Warszawa: Wydawnictwo Naukowe PWN.

Jakubowska-Branicka, I. (2020). Teoretyczne i prawne definicje mowy nienawiści. Granice wolności słowa. W: U. Jakubowska, P. Szarota (red.), Nienawiść w przestrzeni publicznej (ss. 6-32). Warszawa: Wydawnictwo Naukowe PWN.

Jaszczyk-Grzyb, M. (2020). Mowa nienawiści jako przedmiot badań. Praktyki komunikacyjne nacechowane nienawiścią w dyskursie medialnym. Adeptus, 15, Article 2059. 
Kofta, M., Narkiewicz-Jodko, W., Kobyliński, P. (2011). Deprywacja kontroli a poznanie i postawy międzygrupowe: znaczenie deficytów poznawczych i afektywnych. W: M. Kofta, M. Bilewicz (red.), Wobec obcych. Zagrożenia psychologiczne a stosunki międzygrupowe. Warszawa: Wydawnictwo Naukowe PWN.

Kossowska, M. (2005). Umysł niezmienny... Poznawcze mechanizmy sztywności. Kraków: Wydawnictwo Uniwersytetu Jagiellońskiego.

Kossowska, M., Letki, N., Zaleśkiewicz, T., Wichary, S. (2020). Człowiek w obliczu pandemii. Psychologiczne i społeczne uwarunkowania zachowań w warunkach kryzysu zdrowotnego. Sopot: Wydawnictwo Smak Słowa.

Kossowska, M., Szumowska, E., Szwed, P. (2018). Tolerancja w czasach niepewności. Sopot: Wydawnictwo Smak Słowa.

Kruglanski, A.W., Webster, D.M. (1996). Motivated closing of the mind: „Seizing” and „freezing”. Psychological Review, 103(2), 263-283.

Leets, L., Giles H. (1999). Harmful speech in intergroup encounters: An organizational framework for communication research. Annals of the International Communication Association, 22(1), 91-137.

Linde-Usiekniewicz, J. (2019). Wybrane problemy rozpoznawania językowych cech „nawoływania do nienawiści”. W: M. Zaśko-Zielińska, K. Kredens (red.), Lingwistyka kryminalistyczna. Teoria i praktyka. Wrocław: Wydawnictwo Uniwersytetu Wrocławskiego.

Malinowski, B. (2016). Jak Facebook zamyka nas w bańce informacyjnej. Algorytm filtrujący newsfeed a zjawisko filter bubble. Zarzq̨dzanie Mediami, 4(1), 15-22.

Martinez, I., Garcia, J.F. (2008). Internalization of values and self-esteem among Brazilian teenagers from authoritative, indulgent, authoritarian, and neglectful homes. Adolescence, 43(169), 13-29.

McDevitt, J., Levin, J., Bennett, S. (2002). Hate crime offenders: An expanded typology. Journal of Social Issues, 58(2), 303-317.

McFarland, S. (2010). Authoritarianism, social dominance, and other roots of generalized prejudice. Political Psychology, 31(3), 453-477.

Mennin, D.S., Heimberg, R.G., Turk, C.L., Fresco, D.M. (2005). Preliminary evidence for an emotion dysregulation model of generalized anxiety disorder. Behaviour Research and Therapy, 43(10), 1281-1310.

Mullen, B., Rice, D.R. (2003). Ethnophaulisms and exclusion: The behavioral consequences of cognitive representation of ethnic immigrant groups. Personality and Social Psychology Bulletin, 29, 1056-1067.

Mullen, B., Smyth, J.M. (2004). Immigrant suicide rates as a function of ethnophaulisms: Hate speech predicts death. Psychosomatic Medicine, 66, 343-348.

Müller, K., Carlo, S. (2020). Fanning the Flames of Hate: Social Media and Hate Crime. https://papers.ssrn.com/sol3/papers.cfm?abstract_id=3082972 (dostęp: 22.01.2021).

Niedenthal, P.M., Krauth-Gruber, S., Ric, F. (2006). Psychology of emotion. Interpersonal, experiential, and cognitive approaches. New York: Psychology Press.

Nycz, A., Obrębska, M. (2020). Potrzeba mitu w czasach niepewności. W: M. Obrębska, A. Pankalla (red.), Mity kultury współczesnej. Perspektywa psychoantropologiczna. Poznań: Wydawnictwo Nauk Społecznych i Humanistycznych UAM.

Obrębska, M. (2020). Contempt speech and hate speech: Characteristics, determinants and consequences. Annales Universitatis Mariae Curie-Skłodowska, 33(3), 9-20. 
Ormerod, K. (2018). Why Social Media Is Ruining Your Life. London: Octopus Publishing Group Ltd.

Pratkanis, A., Aronson, E. (2004). Wiek propagandy. Używanie i nadużywanie perswazji na co dzień. Warszawa: Wydawnictwo Naukowe PWN.

Pratto, F., Sidanius, J., Stallworth, L.M., Malle, B.F. (1994). Social dominance orientation: A personality variable predicting social and political attitudes. Journal of Personality and Social Psychology, 67(4), 741-763.

Radkiewicz, P. (2012). Autorytaryzm a brzytwa Ockhama. Warszawa: Wydawnictwo Naukowe Scholar.

Rokeach, M. (1960). The Open and Closed Mind. New York: Basic Books.

Rutjens, B.T., Loseman, A. (2010). The society-supporting self: System justification and cultural worldview defense as different forms of self-regulation. Group Processes \& Intergroup Relations, 13, 241-250.

Schaller, M., Kenrick, D., Neel, R., Neuberg, S. (2017). Evolution and human motivation: A fundamental motives framework. Social \& Personality Psychology Compass, 11(6), 1-15.

Shah, J.Y., Kruglanski, A.W., Thompson, E.P. (1998). Membership has its (epistemic) rewards: Need for closure effects on in-group bias. Journal of Personality and Social Psychology, 75(2), 383-393.

Skarżyńska, K. (2020). Agresja werbalna w publicznych sporach polityków i jej społeczny odbiór. W: U. Jakubowska, P. Szarota (red.), Nienawiść w przestrzeni publicznej (ss. 122-146). Warszawa: Wydawnictwo Naukowe PWN.

Soral, W., Bilewicz, M., Winiewski, M. (2018). Exposure to hate speech increases prejudice through desensitization. Aggressive Behavior, 44, 136-146.

Stefaniak, A., Bilewicz, M., Winiewski, M. (2015). Uprzedzenia w Polsce. Warszawa: Liberi Libri.

Sullivan, D., Landau, M.J., Rothschild, Z.K. (2010). An existential function of enemyship: Evidence that people attribute influence to personal and political enemies to compensate for threats to control. Journal of Personality and Social Psychology, 98, 434-449.

Szczepaniak-Kozak, A., Lankiewicz, H. (2017). Wybrane aspekty mowy nienawiści w Polsce. Lingwistyka Stosowana, 21, 135-147.

Tafarodi, R.W., Swann, W.B., Jr. (1995). Self-liking and self-competence as dimensions of global self-esteem: Initial validation of a measure. Journal of Personality Assessment, 65(2), 322-342.

Tokarczuk, O. (2020). Okna. Gazeta Wyborcza, 4.04.2020.

Van Hiel, A., Pandelaere, M., Duriez, B. (2004). The impact of need for closure on conservative beliefs and racism: Differential mediation by authoritarian submission and authoritarian dominance. Personality and Social Psychology Bulletin, 30(7), 824-837.

Vedeler, J.S., Olsen, T., Eriksen, J. (2019). Hate speech harms: A social justice discussion of disabled Norwegians' experiences. Disability \& Society, 34(3), 1-16.

Winiewski, M., Hansen, K., Bilewicz, M., Soral, W., Świderska, A., Bulska, D. (2017). Mowa nienawiści, mowa pogardy. Raport z badania przemocy werbalnej wobec grup mniejszościowych. Warszawa: Fundacja im. Stefana Batorego.

Wypych, M., Soral, W., Bilewicz, M. (2020). Poza nienawiść. O emocjonalnym podłożu krzywdzącego języka. W: U. Jakubowska, P. Szarota (red.), Nienawiść w przestrzeni publicznej (ss. 97-121). Warszawa: Wydawnictwo Naukowe PWN. 